Supporting Information

\title{
Solvent-Dictated Lithium Sulfur Redox Reactions: An Operando UV-vis Spectroscopic Study
}

Qingli Zou, Yi-Chun Lu*

Electrochemical Energy and Interfaces Laboratory, Department of Mechanical and Automation Engineering, The Chinese University of Hong Kong, Shatin, N.T. 999077, Hong Kong SAR, China.

*Email: yichunlu@mae.cuhk.edu.hk 


\section{EXPERIMENTAL SECTION}

Operando UV-Vis spectroscopy cell assembling. Figure S1 shows the schematic illustration of the operando UV-Vis cell. The $1.0 \mathrm{~mm}$ micro cuvette was selected as cell body. The gold mesh was employed as a working electrode. The counter electrode was lithium metal foil. The $\mathrm{Ag} / \mathrm{Ag}^{+}$reference electrode (ALS; Japan) consisted of a glass tube filled with $0.01 \mathrm{M} \mathrm{AgNO}_{3}, 0.1 \mathrm{M}$ tetrabutylammonium perchlorate (TBAP) in acetonitrile. $2.0 \mathrm{mM} \quad \mathrm{S}_{8} \quad$ (Sigma Aldrich, >99.5\%) and $1.0 \mathrm{M}$ lithium bis(trifluoromethanesulfonyl)imide (LiTFSI) (Sigma Aldrich, 99.95\%) were dissolved in pure DMSO (Sigma Aldrich, 99.7\%) and DOL (Sigma Aldrich, 99.8\%): DME(Sigma Aldrich, 99.9\%) (Volume ratio 1:1) and stirred overnight. The cell was assembled in an Argon-filled glove box $\left(\mathrm{H}_{2} \mathrm{O}<1.0 \mathrm{ppm}, \mathrm{O}_{2}<1.0 \mathrm{ppm}\right.$, Etelux, China).

The potential calibration between the $\mathrm{Ag} / \mathrm{Ag}^{+}$reference and lithium foil was measured in the electrolyte of interest each time before the electrochemical test. The $\mathrm{CV}$ scans were obtained at a scanning rate of $1.0 \mathrm{mV} / \mathrm{s}$.

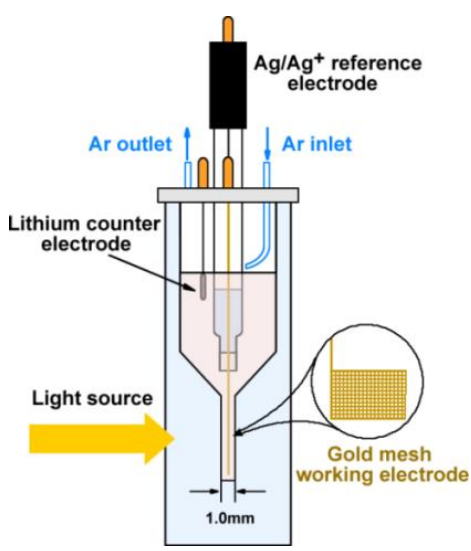

Figure S1. Structure of three electrode operando UV cell. 
Operando UV-Vis spectroscopy measurement. The UV-Vis spectroscopic (SEC2000; ALS; Japan) was switched on at least 30 min before the test to have a stabilized light source. The reference was measured every time before and after the test. The UV-Vis measurement was started at the same time with the electrochemical test and the data was collected every 0.5 second. The UV-Vis cell was saturated with pure Argon gas (N5.0, HKO, Hong Kong) during the entire measurement.

Preparation of polysulfide. Polysulfide samples with nominal composition " $\mathrm{Li}_{2} \mathrm{~S}_{8}$ ", " $\mathrm{Li}_{2} \mathrm{~S}_{6}$ ", " $\mathrm{Li}_{2} \mathrm{~S}_{4}$ " are prepared following the method developed by Rauh et al. Briefly, lithium sulfide (Sigma Aldrich, 99.98\%) and sulfur were mixed with magnetic stirring at room temperature for 24 hours in various solvents in an Ar-filled glovebox to yield " $\mathrm{Li}_{2} \mathrm{~S}_{8}$ ", " $\mathrm{Li}_{2} \mathrm{~S}_{6}$ ", " $\mathrm{Li}_{2} \mathrm{~S}_{4}$ " with a concentration of $2 \mathrm{mM}$ following:

$\mathrm{Li}_{2} \mathrm{~S}+(\mathrm{n}-1) / \mathrm{S}_{8} \rightarrow \mathrm{Li}_{2} \mathrm{~S}_{\mathrm{n}}$ where $\mathrm{n}=4,6,8$.

Li-S catholyte cell Assembling. $4.0 \mathrm{mM} \mathrm{S}_{8}$ was first dissolved in various electrolytes at $50^{\circ} \mathrm{C}$ and stirred for 12 hours. Subsequently, 1.0 M LiTFSI was then added in the sulfur containing electrolyte. The catholyte was then cool down to room temperature for more than 24 hours prior to use. No precipitation can be observed (Figure S2). The solubility of $S_{8}$ was previously suggested between $2-4 \mathrm{mM}$ in DMF/DMSO/DME after stirring at room temperature for 96 hours and resting for 72 hours. ${ }^{2}$ In our preparation, we show that $4 \mathrm{mM}$ elemental sulfur can be dissolved in shorter time (12 hours) at an elevated temperature $\left(50{ }^{\circ} \mathrm{C}\right)$ and $n o$ precipitation can be observed after letting the solution stand at room temperature for more than 24 hours (Figure S2). This suggests that increasing temperature helps to overcome the 
activation barriers during the dissolution of elemental sulfur. In fact, $4 \mathrm{mM} \mathrm{S}_{8}$ in DMSO or DOL:DME was used in our previous work ${ }^{3}$ and that of Gorlin et $\mathrm{al}^{4}$.

The Li-S catholyte cells were assembled accordingly to a previous study. ${ }^{3}$ Briefly, a piece of Li foil ( $\Phi 16$, Shenzhen Meisen Electromechanical Co. Ltd., China) was placed on the stainless steel negative cell case. Then $60 \mu \mathrm{l}$ triethylene glycol dimethyl ether (TEGDME) electrolyte with 1 M LiTFSI was added onto the Li foil. One piece of glass fiber (QMA, $\Phi 16$, Whatman) was placed onto the Li foil followed by a piece of $\mathrm{Li}$ ion conducting glass ceramic (LICGC, $\Phi 19 \times 0.15 \mathrm{~mm}$, Ohara, Japan). One carbon paper (HCP010N, Shanghai Hesen Electric Co. Ltd., China) was placed on the top and $10 \mu \mathrm{l}$ catholyte $\left(4 \mathrm{mM} \mathrm{S}_{8}-1.0 \mathrm{M}\right.$ LiTFSI in DMSO, $4 \mathrm{mM} \mathrm{S}_{8}-1.0 \mathrm{M}$ LiTFSI in DMF or $4 \mathrm{mM} \mathrm{S}_{8}-1.0 \mathrm{M}$ LiTFSI in DOL:DME) was added. The Li-S catholyte cell was assembled in the Argon-filled glove box. 


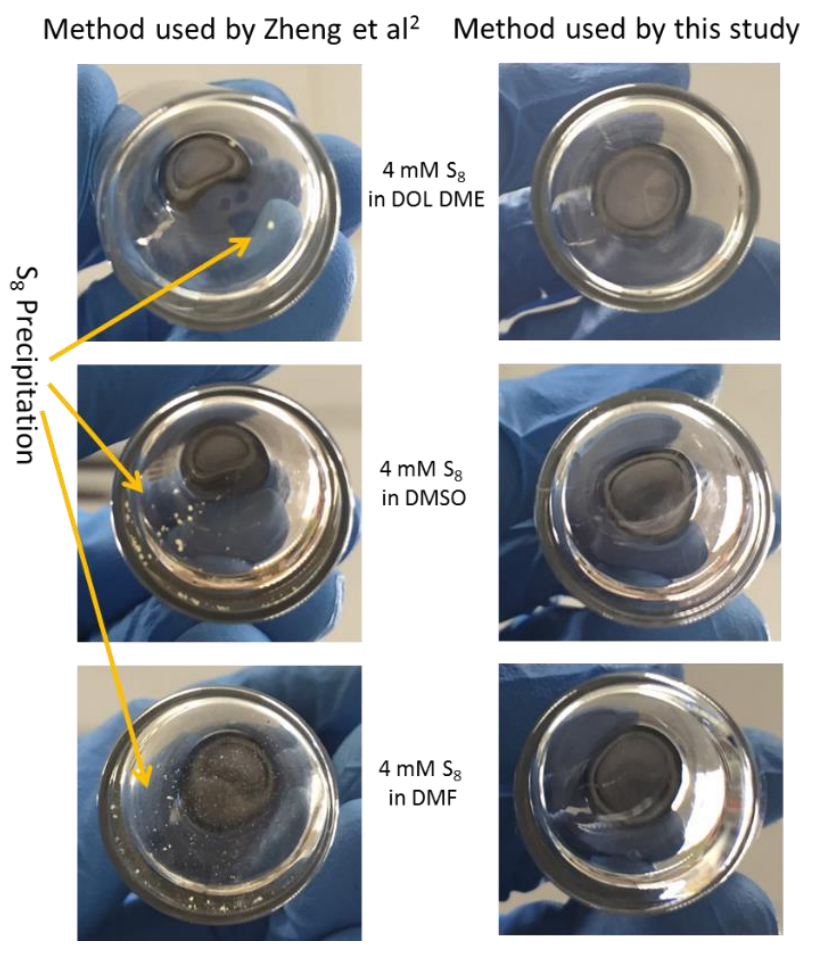

Figure S2. Comparison of different solvation methods ${ }^{2}$ of $4 \mathrm{mM} \mathrm{S}_{8}$ in $1 \mathrm{M}$ LiTFSI in various electrolyte solvents. 

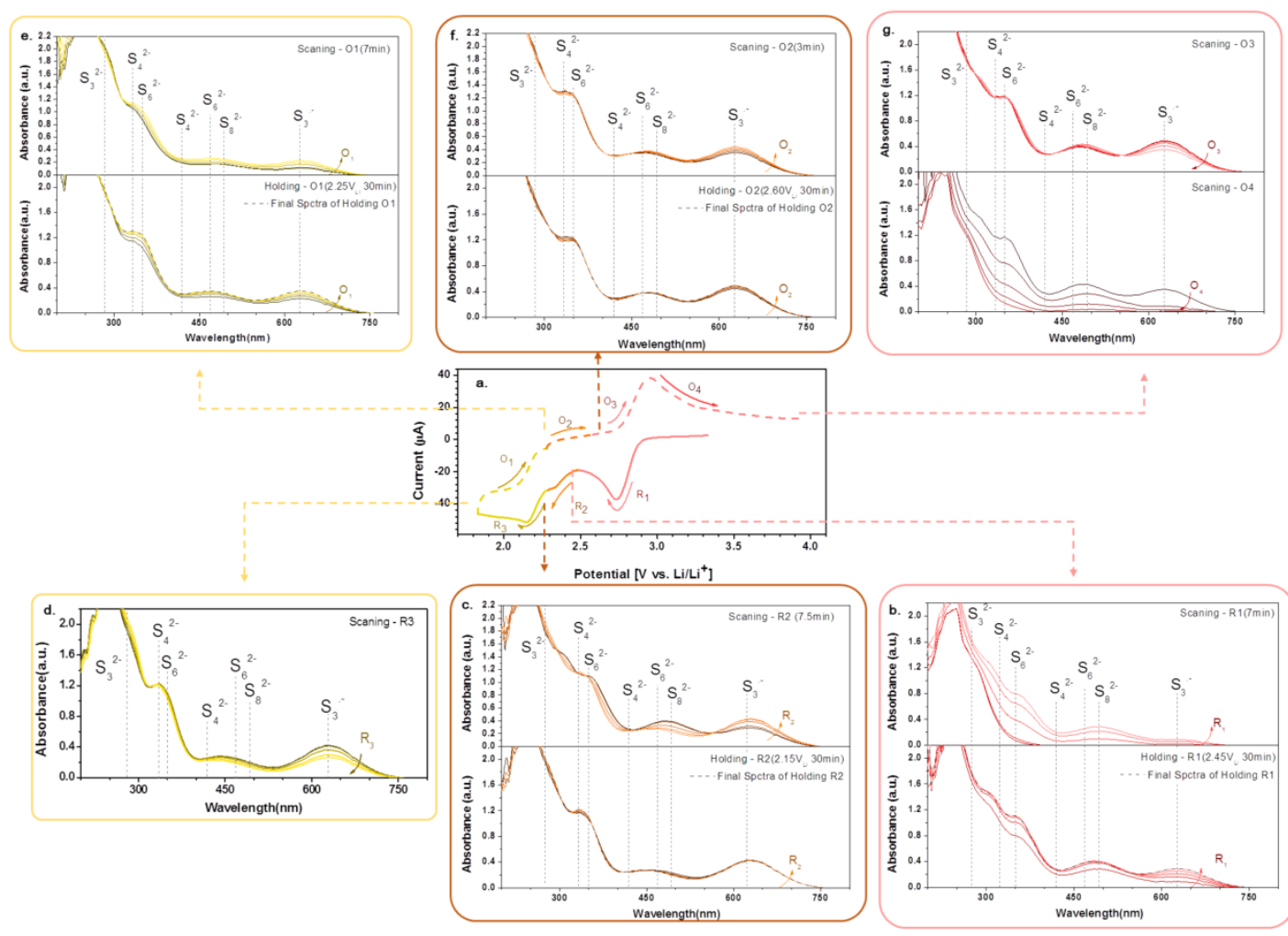

Figure $\mathrm{S} 3$. (a) CV of $2.0 \mathrm{mM} \mathrm{S}_{8}-1.0 \mathrm{M}$ LiTFSI in DMSO. (Each reaction step was scanned separately with potential holding experiment in between and reconstructed with current adjustment - only for visual aid) (b-g) Operando UV-Vis spectra of each reaction steps (Color from dark to light with the arrow in each figure represents the changes over time, UV band attribution: $\mathrm{S}_{8}{ }^{2-}$ at $492 \mathrm{~nm}^{5-9}, \mathrm{~S}_{6}{ }^{2-}$ at $475 \mathrm{~nm}$ and $350 \mathrm{~nm}^{8-9}$, $\mathrm{S}_{4}{ }^{2-}$ at $420 \mathrm{~nm}$ and $325 \mathrm{~nm}^{6,8-11}, \mathrm{~S}_{3}{ }^{2-}$ at $270 \mathrm{~nm}^{8}, \mathrm{~S}_{3}{ }^{--}$at $\left.617 \mathrm{~nm}^{5,7-9,12-13}\right)$. 


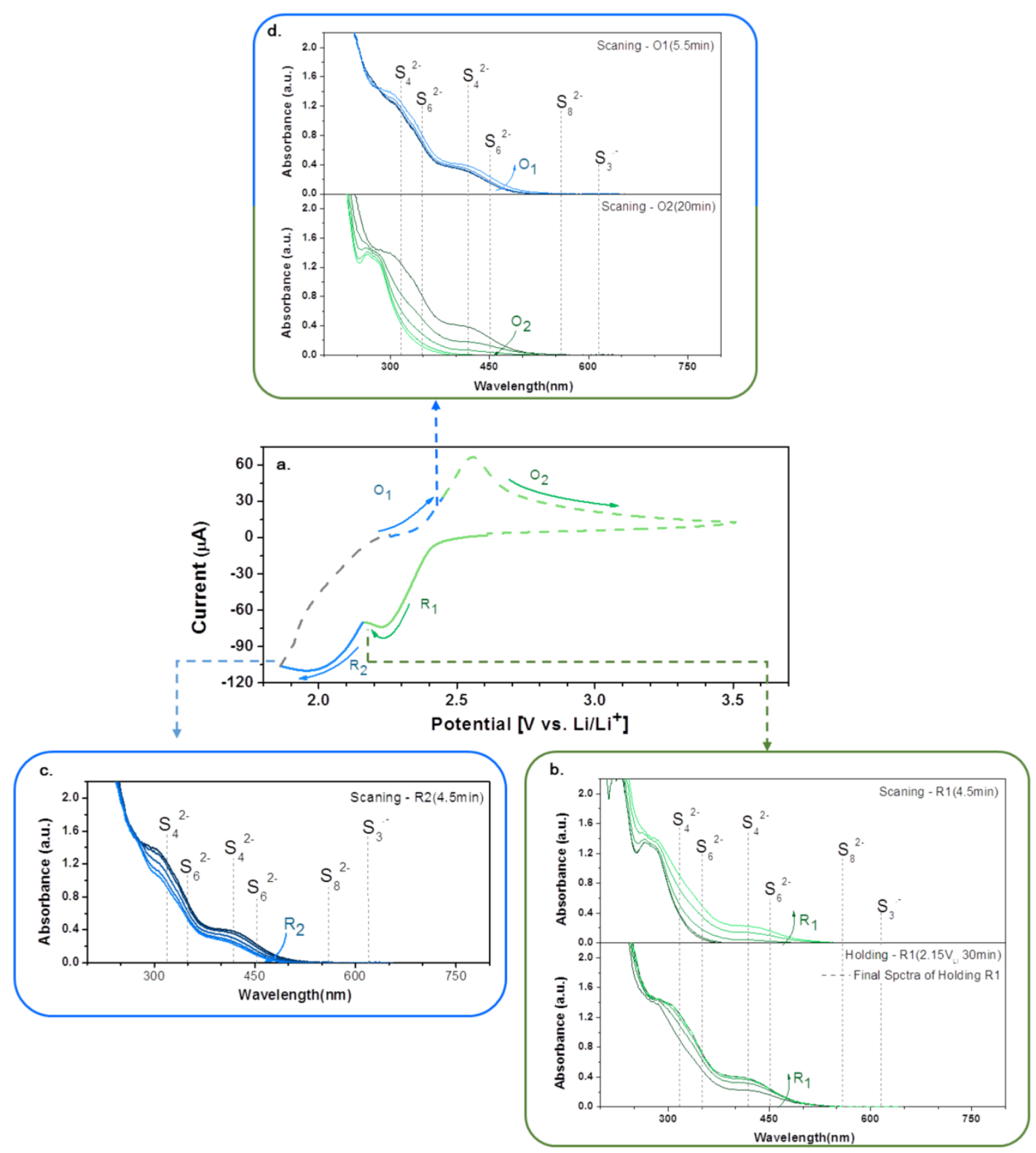

Figure S4. (a) CV of $2.0 \mathrm{mM} \mathrm{S}_{8}-1.0 \mathrm{M}$ LiTFSI in DOL: DME (1:1) (Each reaction step was scanned separately with potential holding experiment in between and reconstructed with current adjustment - only for visual aid). (b-d) Operando UV-Vis absorption spectra of each reaction steps (Color from dark to light with the arrow in each figure represents the changes over time, UV band attribution: $\mathrm{S}_{8}{ }^{2-}$ at $560 \mathrm{~nm}^{14}$, $\mathrm{S}_{6}{ }^{2-}$ at $470 \mathrm{~nm}$ and $350 \mathrm{~nm}^{14}, \mathrm{~S}_{4}{ }^{2-}$ at $420 \mathrm{~nm}$ and $320 \mathrm{~nm}^{14-15}, \mathrm{~S}_{3}{ }^{--}$at $617 \mathrm{~nm}^{14}$ ). 


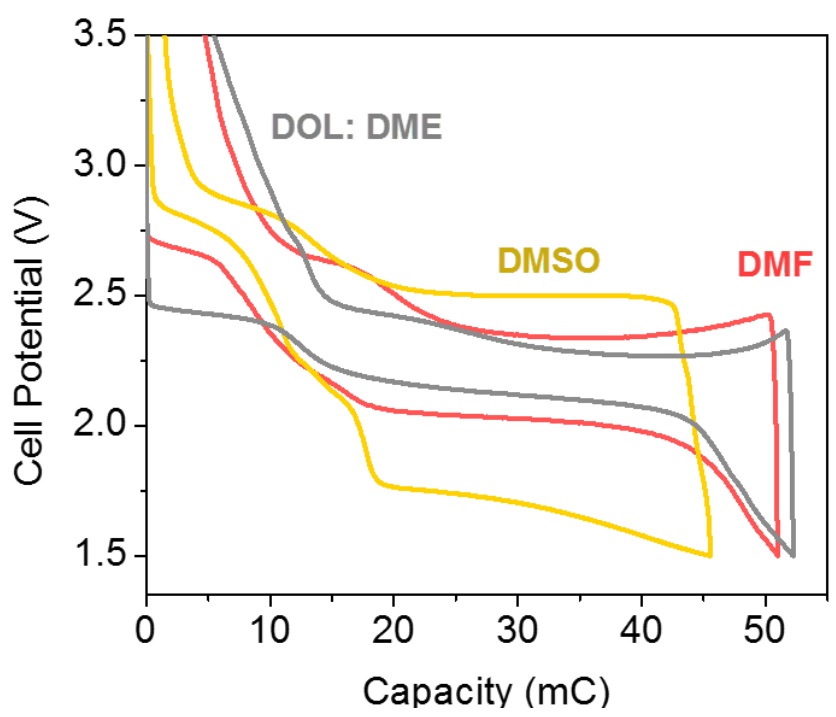

Figure S5. Galvanostatic discharge and charge profiles of $\mathrm{Li}-\mathrm{S}$ catholyte cell consist of $10 \mu \mathrm{L}$ of 4.0 mM S8-1.0 M LiTFSI in DMSO, DMF and DOL: DME with operation rate at $1 \mathrm{C}(17 \mu \mathrm{A})$.
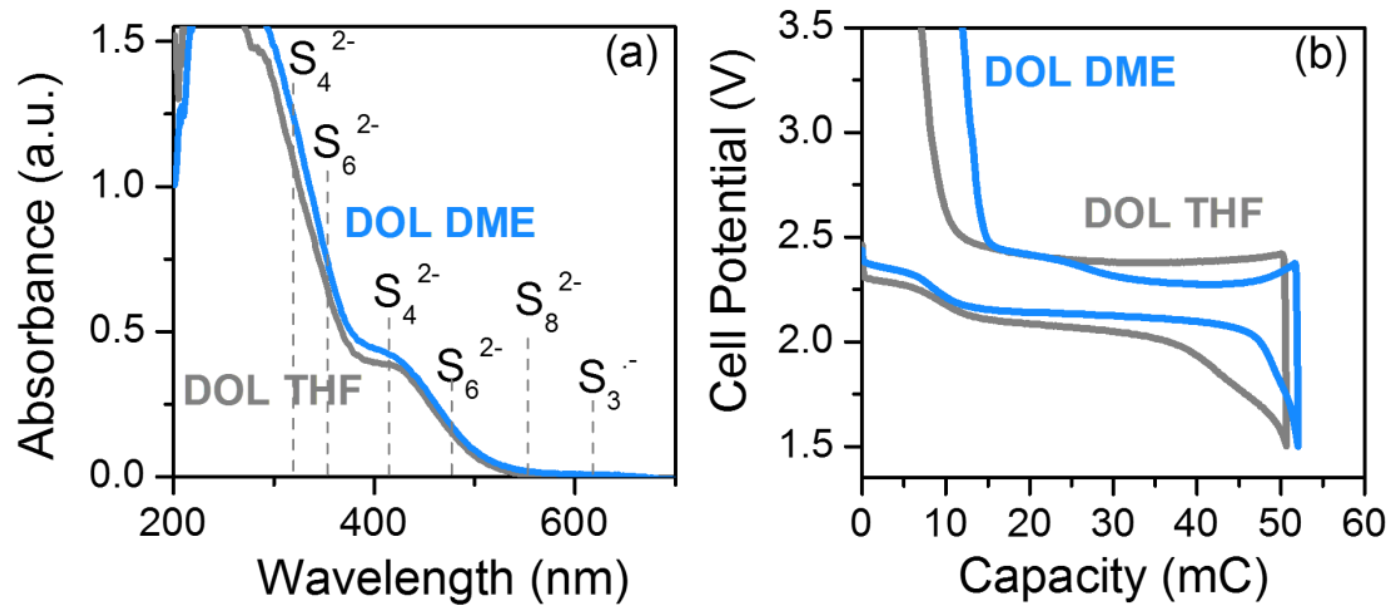

Figure S6. (a) UV-Vis absorption spectra of $2.0 \mathrm{mM}$ nominal $\mathrm{S}_{8}{ }^{2-}$ in DOL: DME (1:1) and DOL: THF (1:1). (b) Galvanostatic discharge and charge profiles of $\mathrm{Li}-\mathrm{S}$ catholyte cell consist of $10 \mu \mathrm{L}$ of $4.0 \mathrm{mM} \mathrm{S}_{8^{-}} 1.0 \mathrm{M}$ LiTFSI in DOL: DME (1:1) or DOL: THF (1:1) with operation rate at $1 \mathrm{C}(17 \mu \mathrm{A})$. 


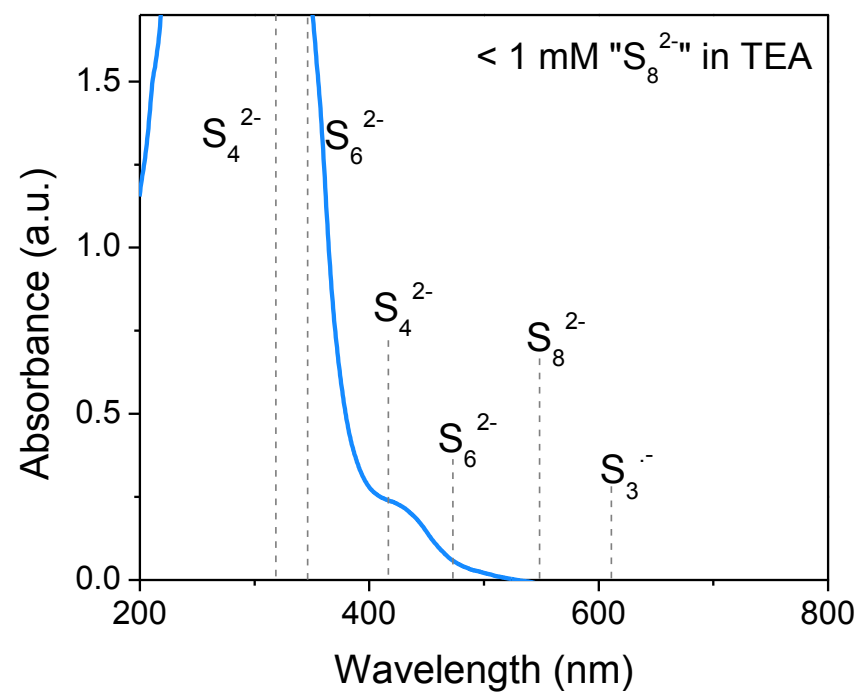

Figure S7. UV-Vis absorption spectra of nominal $\mathrm{S}_{8}{ }^{2-}(<1.0 \mathrm{mM}$ due to low solubility) in Triethanolamine (TEA) with $10 \mathrm{~mm}$ UV cuvette.

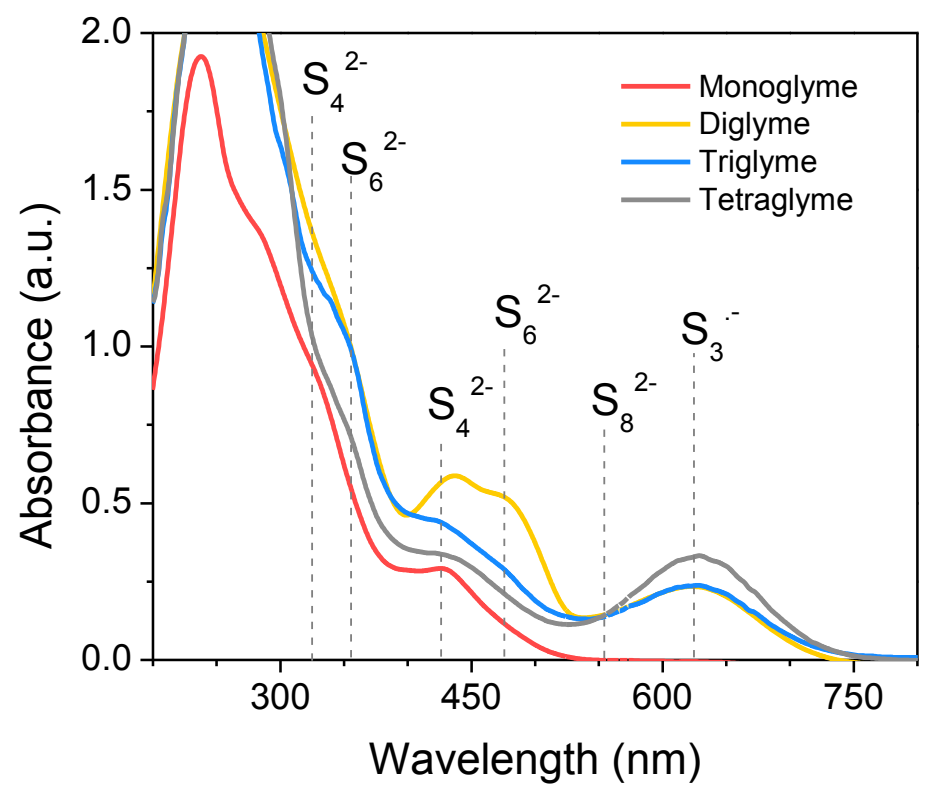

Figure S8. UV-Vis absorption spectra of $0.2 \mathrm{mM}$ nominal $\mathrm{S}_{8}{ }^{2-}$ in DME (monoglyme), diglyme, triglyme and tetraglyme (TEGDME) with 10mm UV cuvette. 
Table S1. Donor number and dielectric constant of solvents ${ }^{16-19}$

\begin{tabular}{|c|c|c|}
\hline & $\begin{array}{c}\text { Donor Number } \\
\text { (DN) }\end{array}$ & $\begin{array}{c}\text { Dielectric constant } \\
(\varepsilon)\end{array}$ \\
\hline $\begin{array}{c}\text { 1,2-Dimethoxyethane } \\
\text { (DME, monoglyme) }\end{array}$ & 24 & 7.1 \\
\hline $\begin{array}{c}\text { Diethylene glycol dimethyl ether } \\
\text { (Diglyme) }\end{array}$ & 20 & 7.2 \\
\hline $\begin{array}{c}\text { Triethylene glycol dimethyl ether } \\
\text { (Triglyme) }\end{array}$ & 14 & 7.6 \\
\hline $\begin{array}{c}\text { Tetraethylene glycol dimethyl ether } \\
\text { (TEGDME, Tetraglyme) }\end{array}$ & 17 & 7.8 \\
\hline
\end{tabular}

\section{Reference}

(1) Rauh, R.; Shuker, F.; Marston, J.; Brummer, S. Formation of Lithium Polysulfides in Aprotic Media. J. Inorg. Nucl. Chem. 1977, 39, 1761-1766.

(2) Zheng, D.; Zhang, X.; Li, C.; McKinnon, M. E.; Sadok, R. G.; Qu, D.; Yu, X.; Lee, H.-S.; Yang, X.-Q.; Qu, D. Quantitative Chromatographic Determination of Dissolved Elemental Sulfur in the Non-Aqueous Electrolyte for Lithium-Sulfur Batteries. J. Electrochem. Soc. 2015, 162, A203-A206.

(3) Lu, Y.-C.; He, Q.; Gasteiger, H. A. Probing the Lithium-Sulfur Redox Reactions: A Rotating-Ring Disk Electrode Study. J. Phys. Chem. C 2014, 118, 5733-5741.

(4) Gorlin, Y.; Siebel, A.; Piana, M.; Huthwelker, T.; Jha, H.; Monsch, G.; Kraus, F.; Gasteiger, H. A.; Tromp, M. Operando Characterization of Intermediates Produced in a Lithium-Sulfur Battery. J. Electrochem. Soc. 2015, 162, A1146-A1155.

(5) Gaillard, F.; Levillain, E. Visible Time-Resolved Spectroelectrochemistry: Application to Study of the Reduction of Sulfur (S 8) in Dimethylformamide. $J$. Electroanal. Chem. 1995, 398, 77-87.

(6) Han, D.-H.; Kim, B.-S.; Choi, S.-J.; Jung, Y.; Kwak, J.; Park, S.-M. Time-Resolved In Situ Spectroelectrochemical Study on Reduction of Sulfur in N, N ' -Dimethylformamide. J. Electrochem. Soc. 2004, 151, E283-E290.

(7) Kawase, A.; Shirai, S.; Yamoto, Y.; Arakawa, R.; Takata, T. Electrochemical Reactions of Lithium-Sulfur Batteries: An Analytical Study Using the Organic Conversion Technique. Phys. Chem. Chem. Phys. 2014, 16, 9344-9350.

(8) Kim, B. S.; Park, S. M. In Situ Spectroelectrochemical Studies on the Reduction of Sulfur in Dimethyl Sulfoxide Solutions. J. Electrochem. Soc. 1993, 140, 115-122.

(9) Martin, R. P.; Doub, W. H.; Roberts, J. L.; Sawyer, D. T. Electrochemical Reduction of Sulfur in Aprotic Solvents. Inorg. Chem. 1973, 12, 1921-1925.

(10)Bonnaterre, R.; Cauquis, G. Spectrophotometric Study of the Electrochemical Reduction of Sulphur in Organic Media. J. Chem. Soc., Chem. Commun. 1972, 293-294. 
(11)Rauh, R. D.; Shuker, F. S.; Marston, J. M.; Brummer, S. B. Formation of Lithium Polysulfides in Aprotic Media. J. Inorg. Nucl. Chem. 1977, 39, 1761-1766.

(12)Seel, F.; Guttler, H.-J.; Simon, G.; Wieckowski, A. Colored Sulfur Species in EPD-Solvents. Pure Appl. Chem. 1977, 49, 45-54.

(13) Yu, X.; Manthiram, A. A Class of Polysulfide Catholytes for Lithium-Sulfur Batteries: Energy Density, Cyclability, and Voltage Enhancement. Phys. Chem. Chem. Phys. 2015, 17, 2127-2136.

(14)Barchasz, C.; Molton, F.; Duboc, C.; Leprêtre, J.-C.; Patoux, S.; Alloin, F. Lithium/Sulfur Cell Discharge Mechanism: An Original Approach for Intermediate Species Identification. Anal. Chem. 2012, 84, 3973-3980.

(15)Cañas, N. A.; Fronczek, D. N.; Wagner, N.; Latz, A.; Friedrich, K. A. Experimental and Theoretical Analysis of Products and Reaction Intermediates of Lithium-Sulfur Batteries. J. Phys. Chem. C 2014, 118, 12106-12114.

(16)Aurbach, D.; Weissman, I. In Nonaqueous Electrochemistry, Aurbach, D., Ed. CRC Press: Boca Raton, 1999.

(17)Geoffroy, I.; Willmann, P.; Mesfar, K.; Carre, B.; Lemordant, D. Electrolytic Characteristics of Ethylene Carbonate-Diglyme-Based Electrolytes for Lithium Batteries. Electrochim. Acta 2000, 45, 2019-2027.

(18)Buckley, F.; Maryott, A. A. Tables of Dielectric Dispersion Data for Pure Liquids and Dilute Solutions; US Dept. of Commerce, National Bureau of Standards: U.S.; 1958.

(19)Gutmann, V. Coordination Chemistry in Non-Aqueous Solutions; Springer Science \& Business Media: Austria; 2012. 